\title{
Intercontinental spread of OXA-48 beta-lactamase- producing Enterobacteriaceae over a 11-year period, 2001 to 2011
}

A Potron ${ }^{1}$, L Poirel ${ }^{1,2}$, E Rondinaud $^{1}$, P Nordmann (patrice.nordmann@unifr.ch) ${ }^{1,2}$

1. INSERM U914, Emerging Resistance to Antibiotics, Faculté de Médecine et Université Paris-Sud, K. Bicêtre, France

2. Medical and Molecular Microbiology Unit, Department of Medicine, Faculty of Science,University of Fribourg, Fribourg,

Switzerland

Citation style for this article:

Potron A, Poirel L, Rondinaud E, Nordmann P. Intercontinental spread of OXA-48 beta-lactamase-producing Enterobacteriaceae over a 11 -year period, 2001 to 2011. Euro Surveill. 2013;18(31):pii=20549. Available online: http://www.eurosurveillance.org/ViewArticle.aspx?Articleld=20549

OXA-48 beta-lactamase producers are emerging as an important threat mostly in the Mediterranean area. We report here the molecular epidemiology of a collection of OXA-48 beta-lactamase-positive enterobacterial isolates $(n=107)$ recovered from European and northAfrican countries between January 2001 and December 2011. This collection included 67 Klebsiella pneumoniae, 24 Escherichia coli and 10 Enterobacter cloacae. Using the EUCAST breakpoints, ninety-eight isolates (91.6\%) were of intermediate susceptibility or resistant to ertapenem, whereas $66 \%$ remained susceptible to imipenem. Seventy-five per cent of the isolates coproduced an extended-spectrum beta-lactamase, most frequently CTX-M-15 (77.5\%). Susceptibility testing to non-beta-lactam antibiotics showed that colistin, tigecycline, amikacin, and fosfomycin remain active against most of the isolates. Multilocus sequence typing indicated that the most common sequence types (ST) were ST101 and ST38 for $K$. pneumoniae and $E$. coli, respectively. The $b a_{\mathrm{OXA}-48}$ gene was located on a $62 \mathrm{~kb}$ IncL/M plasmid in $92.5 \%$ of the isolates, indicating that a single plasmid was mainly responsible for the spread of that gene. In addition, this study identified multiple cases of importation of OXA-48 betalactamase producers at least in Europe, and spread of OXA-48 beta-lactamase producers giving rise to an endemic situation, at least in France.

\section{Introduction}

Currently, an emergence of carbapenem resistance in Enterobacteriaceae is reported, mostly related to the spread of carbapenemases [1]. Those carbapenemhydrolysing beta-lactamases belong to the Ambler class A (e.g. KPC), class B (e.g. IMP, VIM and NDM) [1], and class D (e.g. OXA-48 and its variants possessing weaker but significant carbapenemase activity) [2]. OXA-48 had first been identified from a clinical Klebsiella pneumoniae isolate recovered in Istanbul, Turkey, in 2001 [3]. The corresponding gene, namely bla $a_{\mathrm{OXA}-48}$, was then also identified in Escherichia coli and Citrobacter freundii, still in Turkey [4]. For several years, OXA-48 was identified only in Turkey, and almost all OXA-48 beta-lactamase producers were reported from patients hospitalised in Turkey or with a link to that country $[4,5]$. Since 2008 , this gene has been identified in many other countries, most often in $K$. pneumoniae isolates $[2,5-10]$. OXA-48 is now identified in the Middle East and in North African countries, and those countries are considered as reservoirs of OXA-48 beta-lactamase producers [2]. In addition to sporadic cases, an increasing number of outbreaks due to OXA-48-producing $K$. pneumoniae are currently observed, not only in Turkey but also in Belgium, France, Greece, the Netherlands and Spain [2,11-13]. $K$. pneumoniae strains belonging to specific sequence types (ST), such as ST395 and ST101, have been involved in those outbreaks [12,14].

In order to gain further understanding of that phenomenon, our study aimed at comparing the genetic features of OXA-48 beta-lactamase-producing strains recovered from various countries by analysing an existing collection of 107 bla $a_{0 \times 4-48}$-positive enterobacterial isolates. The genetic context and the location of the bla $a_{\text {OXA-48 }}$ gene were investigated, as well as resistance to broad-spectrum beta-lactams and non-beta-lactam antibiotics.

\section{Methods}

\section{Bacterial isolates}

A total of 107 OXA-48 beta-lactamase-producing enterobacterial isolates were investigated retrospectively. Enterobacteriacae producing OXA-48-like beta-lactamases were not included in this study. All isolates had been recovered from clinical specimens except a single isolate (one Serratia marcescens strain from an environmental water sample in Morocco), and had been received between January 2001 and December 2011 in our National Reference Laboratory which is also used as an International Reference Laboratory by many colleagues worldwide who send us their isolates for 
further characterisation. Of identical strains in an outbreak, only one was included in this work. The distribution of clinical samples was as follows: rectal swabs $(n=33)$, urine samples $(n=24)$, blood samples $(n=12)$, wound samples $(n=7)$, respiratory specimens $(n=4)$, catheters $(n=4)$, bone specimens $(n=2)$, peritoneal fluids $(n=2)$, and placenta specimen $(n=1)$. One sample per patient was included. Detailed information could not be obtained for 18 clinical samples. The isolates were identified to species level using the API 20 E system (bioMérieux, La Balme-les-Grottes, France).

\section{Susceptibility testing}

Routine antibiograms were determined by disk diffusion method on Mueller-Hinton ( $\mathrm{MH}$ ) agar (Bio-Rad, Marnes-la-Coquette, France) and interpreted using the guidelines of the Clinical and Laboratory Standards Institute (CLSI) (updated 2012) and of the European Committee on Antimicrobial Susceptibility Testing (EUCAST) for tigecycline and colistin $[15,16]$. In addition, MICs were determined for imipenem, meropenem, ertapenem, cefotaxime, and ceftazidime using E-test (bioMérieux, La Balme-les-Grottes, France). The production of extended-spectrum beta-lactamases (ESBL) was evidenced by a double-disk synergy test performed with cefepime, ceftazidime, and ticarcillin/clavulanic acid disks [17] and more recently by using the rapid ESBL NDP test [18].

\section{PCR and sequencing of beta-}

\section{lactamase-encoding genes}

Whole-cell DNA was extracted using the QiaAmp DNA minikit and following the manufacturer's recommendations (Qiagen, Courtaboeuf, France). All isolates were screened by PCR for the Ambler class A and B carbapenemase-encoding genes bla $a_{\mathrm{KPC}}, b l a_{\mathrm{IMP}}, b l a_{\mathrm{VIM}}$, bla $a_{\mathrm{NDM}}$ [19-20]. For each isolate, the $b a_{0 \times A-48}$ gene was amplified using primers preOXA-48A and preOXA-48B, and subsequently sequenced [21]. Detection of other betalactamase genes such as bla $a_{\mathrm{TEM}}, b l a_{\mathrm{SHV}}, b l a_{\mathrm{CTX}-\mathrm{M}}, b l a_{\mathrm{AmpC}}{ }^{-}$ like, and $b l a_{\mathrm{OXA}-1}$ was performed with internal primers, as described previously $[19,22]$. PCR products were analysed on agarose gel and sequenced by using the amplification primers with an automated sequencer (ABI PRISM 3100; Applied Biosystems). The nucleotide and deduced protein sequences were analysed using software from the National Center for Biotechnology Information (www.ncbi.nlm.nih.gov).

\section{Strain typing}

Multilocus sequence typing (MLST) with seven housekeeping genes $(r p o B, g a p A, m d h$, pgi, phoE, infB and ton $B$ ) was performed for $K$. pneumoniae isolates according to Diancourt et al. [23]. Allele sequences and STs were verified at http://pubmlst.org/Kpneumoniae. Fragments of seven housekeeping genes (adk, fumC, gyrB, icd, mdh, purA and recA) were amplified and sequenced for $E$. coli isolates as described on the following website http://mlst.ucc.ie/mlst/dbs/Ecoli. A different allele number was given to each distinct sequence within a locus, and a distinct ST number was attributed to each distinct combination of alleles. $E$. coli isolates were assigned to the major $E$. coli phylogenetic groups (A, B1, B2, and D) by multiplex PCR, as described [24]. The genetic relationship between the Enterobacter cloacae isolates was studied using Diversilab, a semi-automated typing system based on repetitive sequence-based PCR (rep-PCR) following the manufacturer's instructions (bioMérieux).

\section{Plasmid DNA analysis, transformation and mating-out assays}

Plasmid DNA was extracted from the isolates using the Kieser technique [25]. E. coli NCTC50192, harbouring four plasmids of 154, 66, 48 and $7 \mathrm{~kb}$, was used as plasmid size marker. Plasmid DNAs were analysed by agarose gel electrophoresis. Direct transfer of the carbapenem resistance markers was attempted by liquid mating-out assays at $37^{\circ} \mathrm{C}$, using $E$. coli J53 as recipient, or by electrotransformation of plasmid DNA, using E. coli TOP10 as recipient as reported [3,4]. Selection was performed on agar plates supplemented with ertapenem $(0.5 \mu \mathrm{g} / \mathrm{ml})$ and azide $(100 \mu \mathrm{g} / \mathrm{ml})$ for mating-out assays. In order to search for a possible chromosomal location of the bla $a_{0 \times A-48}$ gene in $E$. coli isolates 19 to 24 , restriction with endonuclease I-Ceul followed by pulsed-field gel electrophoresis (PFGE) analysis was performed as described [26].

\section{Replicon and transposon typing}

PCR-based replicon typing (PBRT) of the main plasmid incompatibility groups reported in Enterobacteriaceae was performed as described [27] and using the specific primers designed from plasmid pOXA-48a [28]. Genetic structures surrounding the $b / a_{0 \times A-48}$ gene were determined according to the Tn1999-like PCR-mapping scheme as described [29].

\section{Results}

\section{Bacterial isolates}

A total of 107 isolates were studied, including $K$. pneumoniae $(\mathrm{n}=67)$, E. coli $(\mathrm{n}=24)$, and E. cloacae $(n=10)$ (Table 1). Other enterobacterial species were identified: Citrobacter koseri $(n=2)$, C. freundii $(n=1)$, Klebsiella oxytoca $(n=1)$, Providencia rettgeri $(n=1)$, and S. marcescens $(n=1)$. They had been isolated in France $(n=61)$, Morocco $(n=22)$, Turkey $(n=11)$, Egypt $(n=3)$, Lebanon $(n=2)$, Tunisia $(n=2)$, Switzerland $(n=2)$, South Africa $(n=2)$, Belgium $(n=1)$, and the Netherlands $(n=1)$, respectively (Table 1 ). Among the 61 strains collected in France, 30 had a history of international travel to the following countries: Morocco $(n=14)$, Tunisia $(n=2)$, Libya $(n=5)$, Algeria $(n=4)$, Egypt $(n=3)$, Senegal $(n=1)$, and Kuwait $(n=1)$. In 12 cases, no travel history from a foreign country was identified. For the remaining 19 cases, no precise travel information could be obtained (Table 1). 


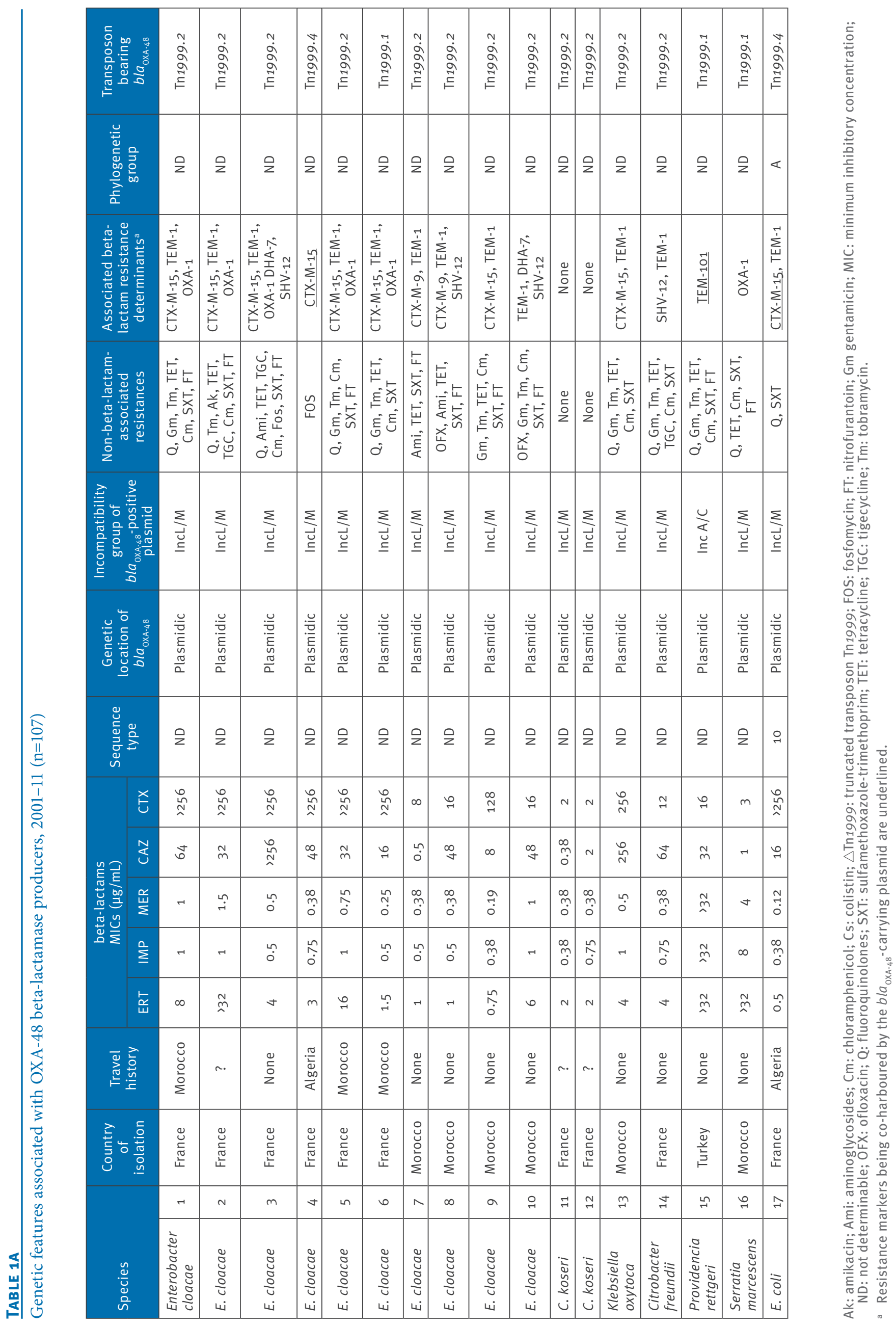




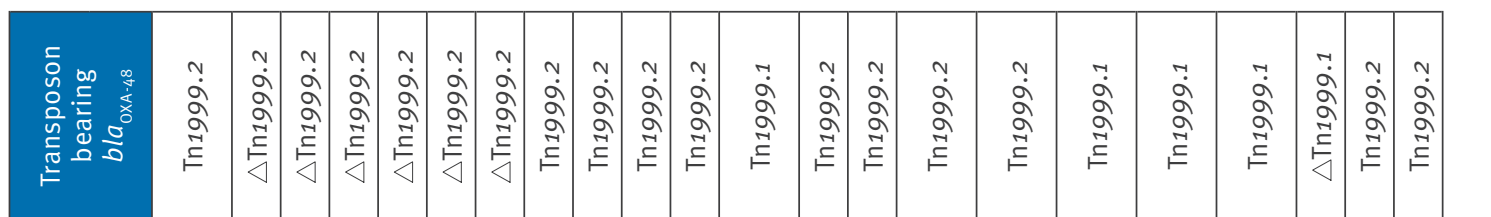

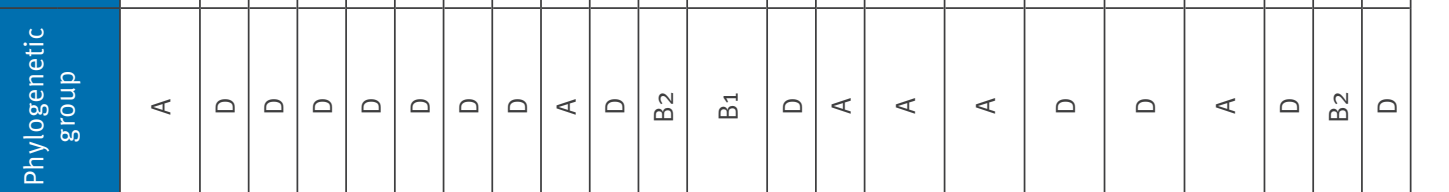

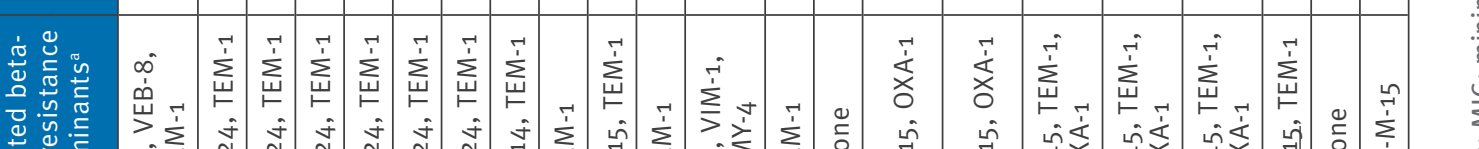

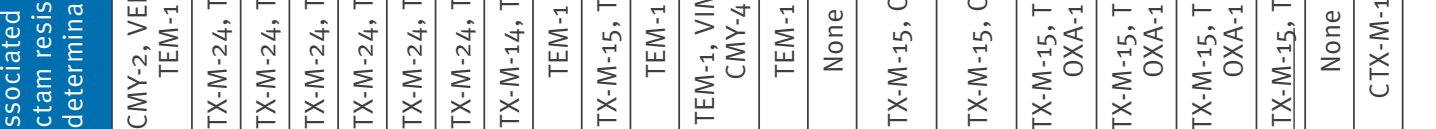

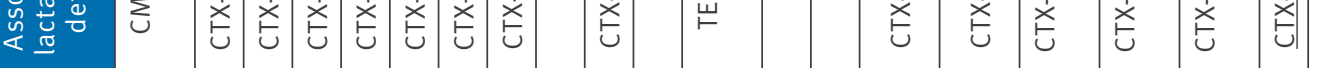

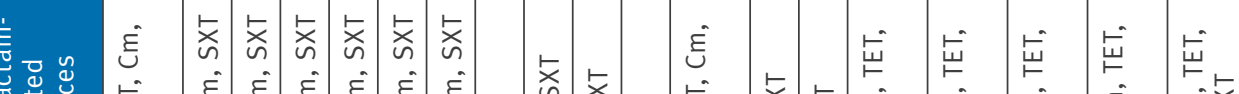

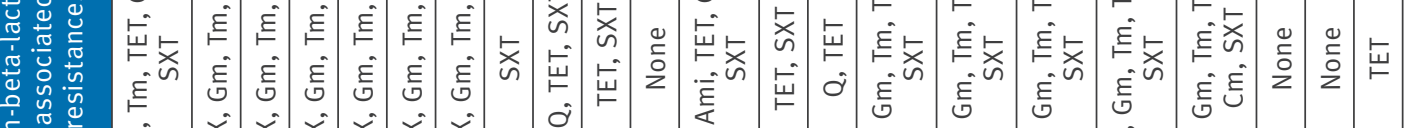

要

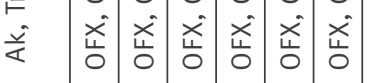

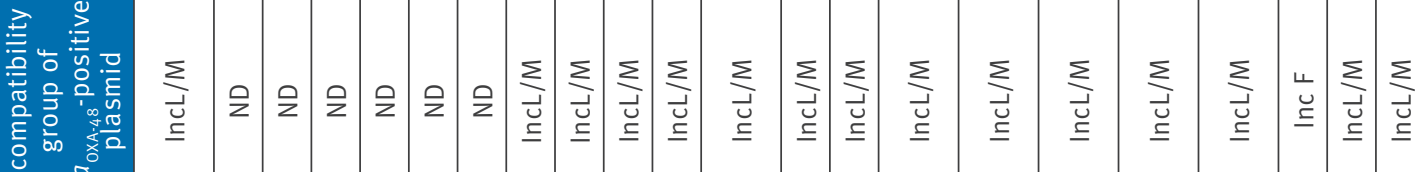

8

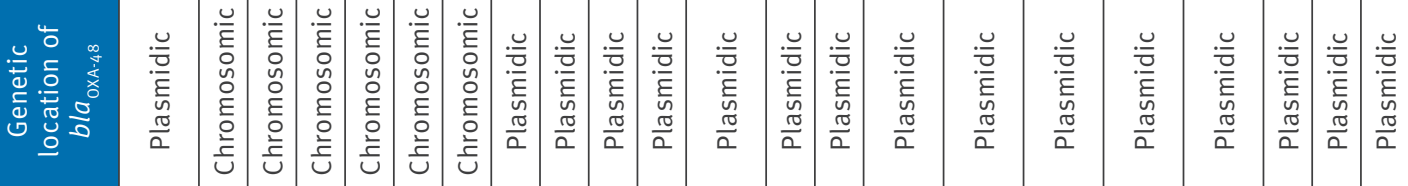

둥

官

를

뜬

承.

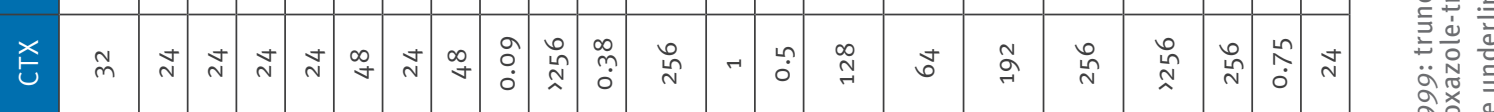

N

宓完

(

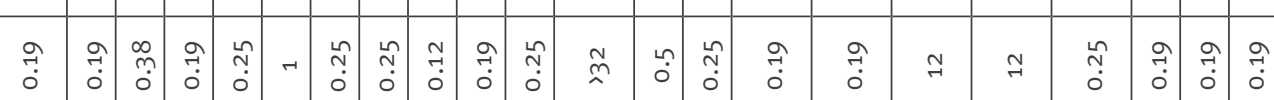

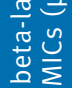

$\stackrel{\varrho}{\Sigma}$

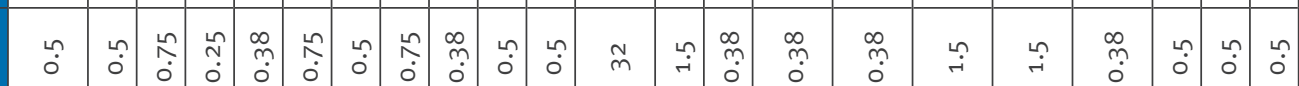

虐

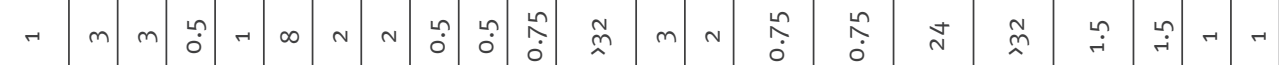

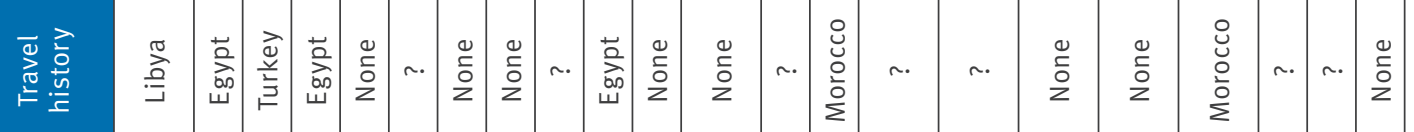

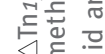

E

䒝

$\ddot{\vartheta} \ddot{\sim}$

훟흐

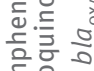

틍응

은 흔

芒兰总

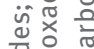

은응 둔

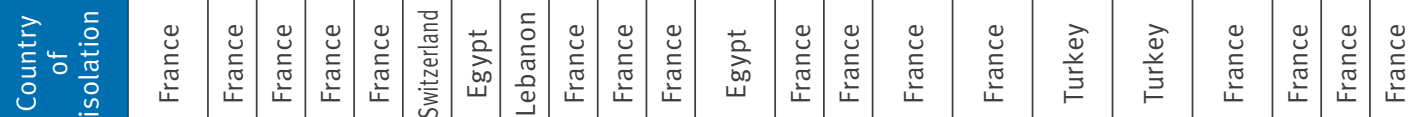

긍 응

용

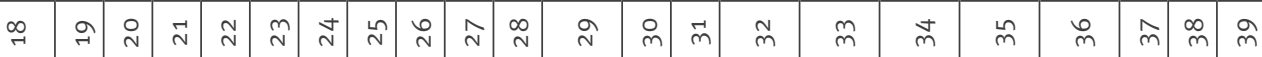

등

莫言离

든흄

站离 


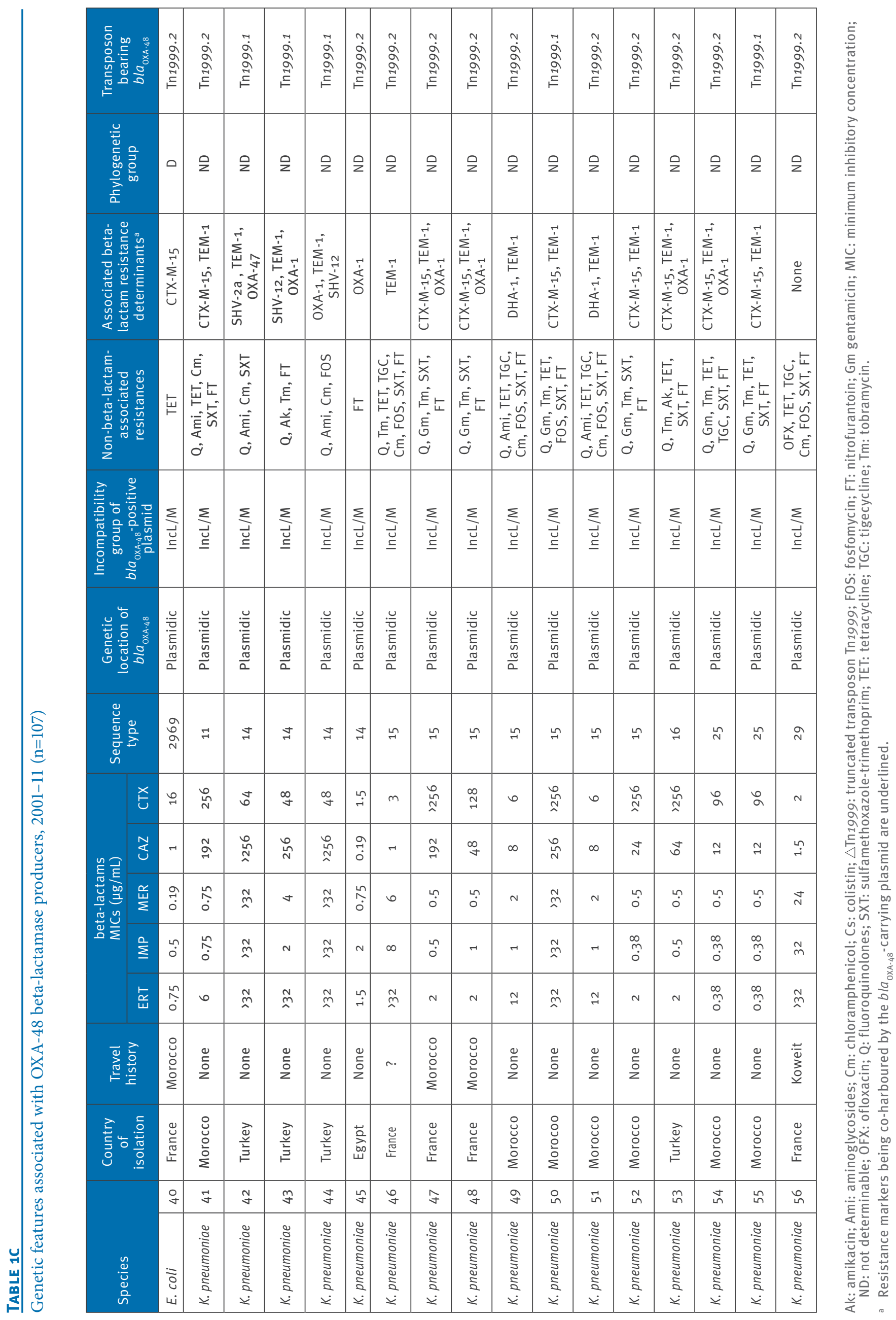




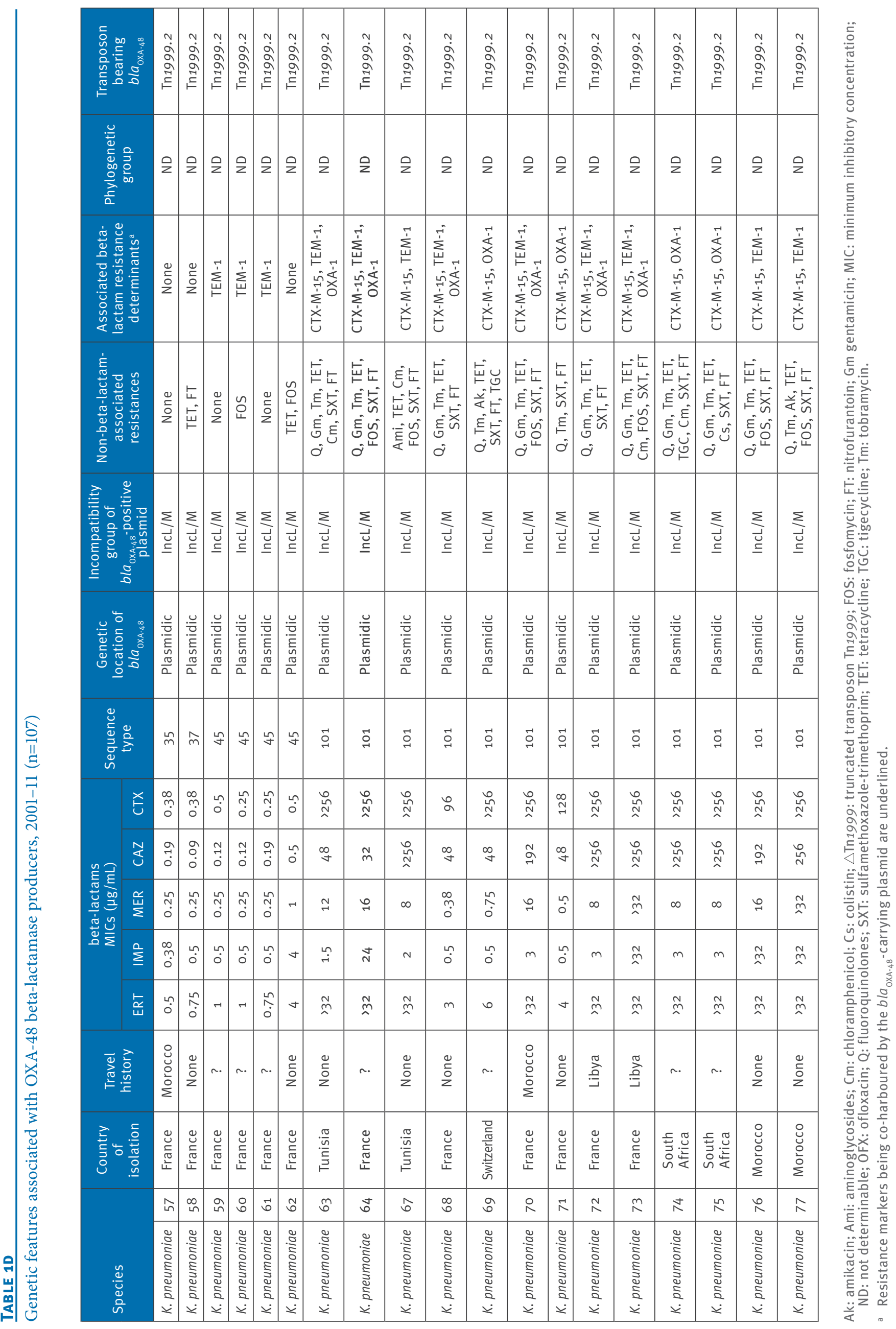




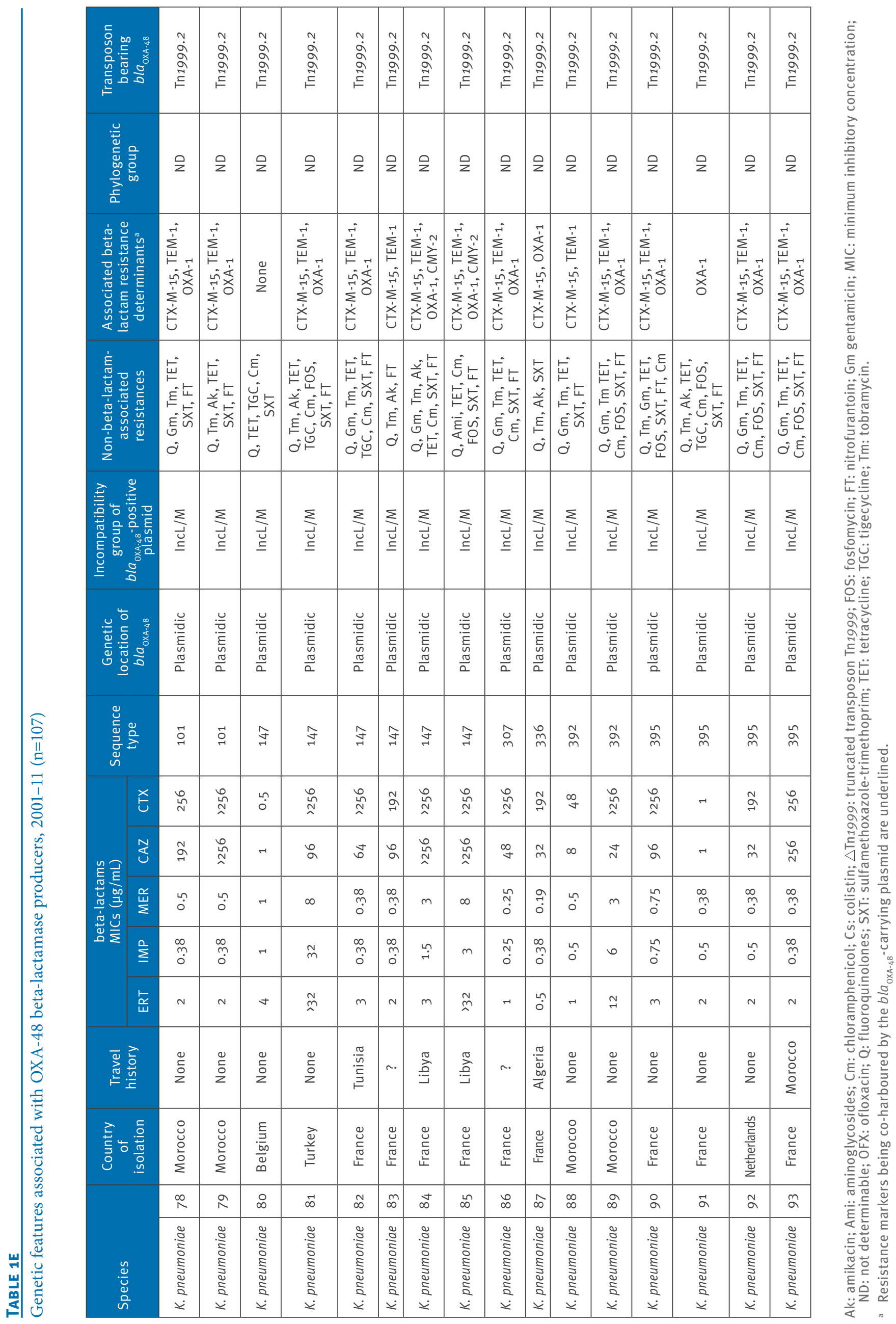




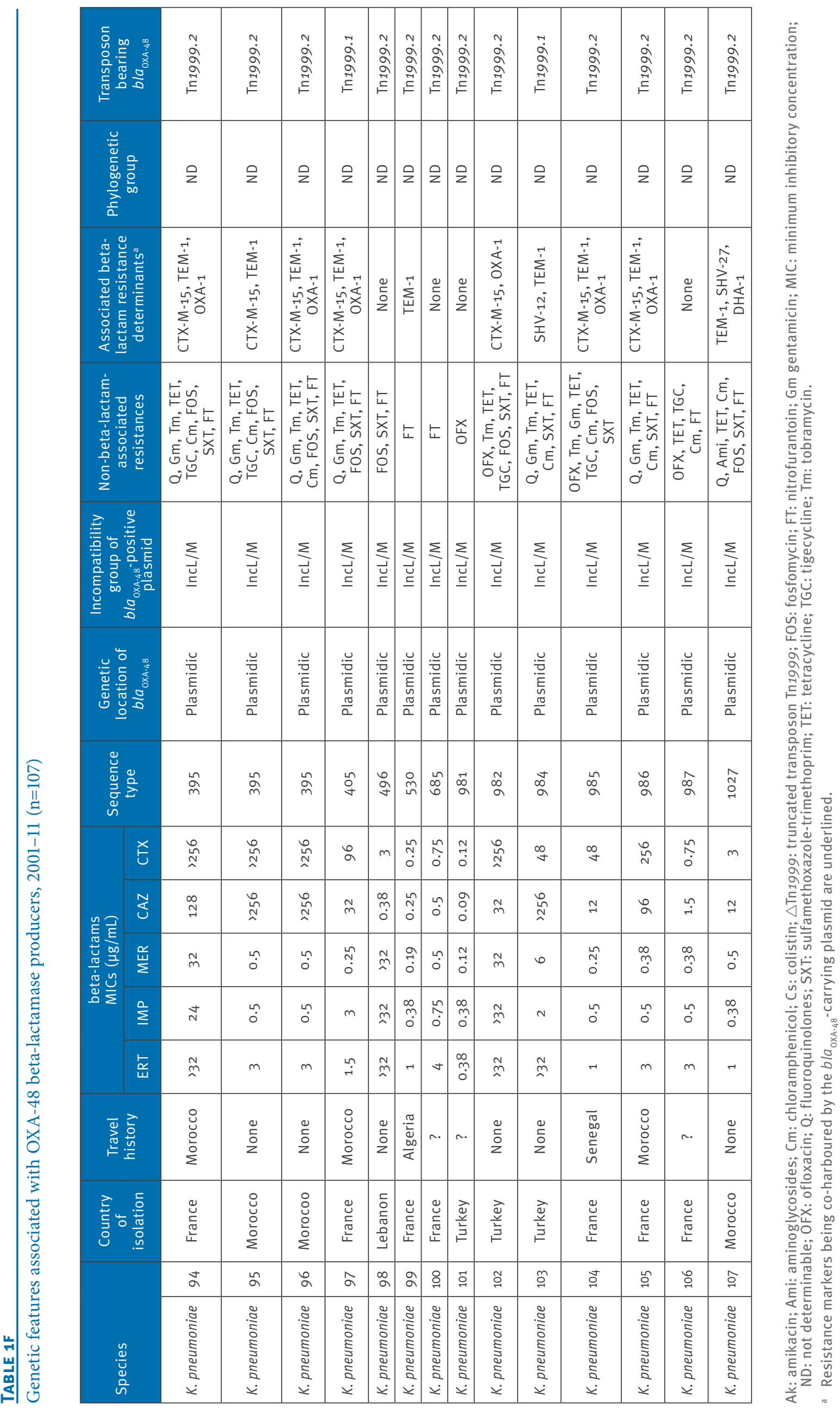




\begin{tabular}{|c|c|c|c|c|}
\hline \multirow{2}{*}{ Species } & \multirow{2}{*}{ Antimicrobial drug } & \multicolumn{3}{|c|}{$\begin{array}{c}\text { Susceptibility } \\
\text { Number (\%) of isolates }\end{array}$} \\
\hline & & Susceptible & Intermediate & Resistant \\
\hline \multirow{3}{*}{ K. pneumoniae $(\mathrm{n}=67)$} & Imipenem & $40(60)$ & $13(19)$ & $14(21)$ \\
\hline & Ertapenem & $5(7)$ & 9 (13) & $53(79)$ \\
\hline & Meropenem & $40(60)$ & $6(9)$ & $21(31)$ \\
\hline \multirow{3}{*}{ E. coli $(n=24)$} & Imipenem & $20(84)$ & $3(12)$ & $1(4)$ \\
\hline & Ertapenem & $4(17)$ & $8(33)$ & $12(50)$ \\
\hline & Meropenem & $21(88)$ & o (o) & $3(12)$ \\
\hline \multirow{3}{*}{ E. cloacae $(n=10)$} & Imipenem & $10(100)$ & o (o) & $\mathrm{o}(\mathrm{o})$ \\
\hline & Ertapenem & o (o) & $3(30)$ & $7(70)$ \\
\hline & Meropenem & $9(90)$ & $1(10)$ & $\mathrm{o}(\mathrm{o})$ \\
\hline
\end{tabular}

The percentages are rounded so as to add up to $100 \%$.

The results in this Table are from E-tests.

Susceptibility to carbapenems and broad-spectrum cephalosporins

Results of susceptibility testing are shown in Tables 2 and 3. According to the CLSI guidelines, $40(60 \%)$ $K$. pneumoniae isolates, $20(83 \%) \mathrm{E}$. coli isolates, and $10(100 \%)$ E. cloacae isolates were susceptible to imipenem (Table 2). In addition, $40(60 \%)$ K. pneumoniae, $21(88 \%)$ E. coli, and 9 (90\%) E. cloacae isolates were susceptible to meropenem. By contrast, 62 (92\%) K. pneumoniae, $20(83 \%)$ E. coli, and $10(100 \%) E$. cloacae isolates were found of intermediate susceptibility or resistant to ertapenem (Table 2). Regarding the broad-spectrum cephalosporins, $73(68 \%)$ and 90 $(84 \%)$ isolates were resistant or of intermediate susceptibility to ceftazidime and cefotaxime, respectively (Table 1 and 3).

\section{Beta-lactamase genes}

Among the 107 OXA-48-producing isolates, 80 (75\%)

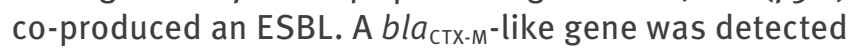
in $71(66 \%)$ of the isolates ( $89 \%$ of the ESBL-producing isolates). Among the different CTX-M variants identified, those belonging to the CTX-M-1 and CTX-M-9 groups accounted for $87.5 \%(n=62)$ and $12.5 \%(n=9)$, respectively. CTX-M-15 was the only representative of the CTX-M-1 group. In the CTX-M-9 group, the $b a_{\text {CTX-M-14 }}$ was identified in a single $E$. coli (Table 1). Two E. cloacae isolates harboured a bla $a_{\text {CTX-M-g }}$ gene and 6 E. coli isolates harboured a bla $a_{\text {CTX-M-24 }}$ gene. The other ESBL determinants were SHV-2a (one $K$. pneumoniae), SHV-12 (three K. pneumoniae, two E. cloacae, and one C. freundii), SHV-27 (one K. pneumoniae) and TEM-101 (P. rettgeri isolate no. 15). Among the SHV-12-producing isolates, one E. cloacae co-produced CTX-M-9 (Table 1). In addition, a novel VEB variant, namely VEB-8, was identified in a single $E$. coli isolate from Libya that co-produced CMY-2 (E. coli 18). VEB-8 differed from VEB- 5 by a single amino acid substitution (GenBank accession number JX679208) [30,31]. It is interesting to note that ESBLs were not related to date or geographic area of isolation.

Furthermore, nine isolates (8.5\%) co-produced a plasmid-mediated AmpC-type beta-lactamase. Four isolates (3.8\%) produced a CMY-type beta-lactamase, namely CMY-4 in a single E. coli isolate from Egypt and CMY-2 in three isolates (a single $E$. coli and two K. pneumoniae isolates from Libya). Five isolates ( $5 \%$ ) produced a DHA-like AmpC, namely DHA-1 in three K. pneumoniae isolates and DHA-7 in two E. cloacae isolates. All the DHA-producing isolates originated from Morocco. A single isolate (E. coli 29 from Egypt) co-produced OXA48 and another carbapenemase, namely VIM-1, in addition to CMY-4. The non-ESBL beta-lactamases TEM-1 and OXA-1 were detected in $79(74 \%)$ and $47(44 \%)$ isolates, respectively.

\section{Susceptibility to non-beta-lactam antibiotics}

Results of susceptibility testing for non-beta-lactam antibiotics are shown in Table 3. Four antibiotics were active against the majority of the isolates; 104 (99\%) of the 107 isolates were susceptible to colistin, $90(84.1 \%)$ to tigecycline, $83(77.6 \%)$ to amikacin, and $77(72 \%)$ to fosfomycin. Conversely, 84 (78.5\%) of the 107 isolates were resistant to sulfamethoxazole-trimethoprim, 72 $(67.3 \%)$ to tetracycline, $64(59.8 \%)$ to ciprofloxacin, and 61 (57\%) to gentamicin. Resistant isolates that produced an ESBL were mostly resistant also to non-betalactam antibiotics (Table 3). 


\begin{tabular}{|c|c|c|c|c|c|c|c|c|c|}
\hline \multirow{3}{*}{$\begin{array}{l}\text { Antimicrobial } \\
\text { drug }\end{array}$} & \multicolumn{9}{|c|}{$\begin{array}{c}\text { Susceptibility } \\
\text { Number (\%) of isolates }\end{array}$} \\
\hline & \multicolumn{3}{|c|}{ Susceptible } & \multicolumn{3}{|c|}{ Intermediate } & \multicolumn{3}{|c|}{ Resistant } \\
\hline & Total & ESBL & Non-ESBL & Total & ESBL & Non-ESBL & Total & ESBL & Non-ESBL \\
\hline Ceftazidime & $34(31.8)$ & $10(9.4)$ & $24(22.4)$ & $9(8.4)$ & $7(6.5)$ & $2(1.9)$ & $64(59.8)$ & $63(58.9)$ & $1(0.9)$ \\
\hline Cefotaxime & $17(15.9)$ & o (o) & $17(15.9)$ & $8(7.5)$ & $1(1.0)$ & $7(6.5)$ & $82(76.6)$ & $79(73.8)$ & $3(2.8)$ \\
\hline Tetracycline & $34(31.8)$ & $21(19.6)$ & $13(12.2)$ & $1(0.9)$ & $1(0.9)$ & $\mathrm{o}(\mathrm{o})$ & $72(67.3)$ & $58(54.2)$ & 14 (13.1) \\
\hline Tigecycline & $90(84.1)$ & $69(64.5)$ & $21(19.6)$ & $5(4.7)$ & $4(3.7)$ & $1(1.0)$ & $12(11.2)$ & $7(6.5)$ & $5(4.7)$ \\
\hline Fosfomycin & $77(72.0)$ & $58(54.2)$ & $19(17.8)$ & $2(1.8)$ & $2(1.8)$ & $\mathrm{o}(0)$ & $28(26.2)$ & $20(18.7)$ & $8(7.5)$ \\
\hline $\begin{array}{l}\text { Sulfamethoxazol/ } \\
\text { trimethoprim }\end{array}$ & $23(21.5)$ & $7(6.5)$ & $16(15.0)$ & o (o) & o (o) & o (o) & $84(78.5)$ & $73(68.2)$ & $11(10.3)$ \\
\hline Colistin & $104^{\mathrm{a}}(99.0)$ & $78(74.3)$ & $26(24.7)$ & $\mathrm{o}(0)$ & $\mathrm{o}(\mathrm{o})$ & $\mathrm{o}(0)$ & $1(1.0)$ & $1(1.0)$ & $\mathrm{o}(0)$ \\
\hline Ciprofloxacin & $39(36.4)$ & $21(19.6)$ & $18(16.8)$ & $4(3.8)$ & $4(3.8)$ & $\mathrm{o}(\mathrm{o})$ & $64(59.8)$ & $55(51.4)$ & $9(8.4)$ \\
\hline Amikacin & $83(77.6)$ & $60(56.1)$ & $23(21.5)$ & $15(14.0)$ & 14 (13.1) & $1(0.9)$ & $9(8.4)$ & $6(5.6)$ & $3(2.8)$ \\
\hline Gentamicin & $43(40.2)$ & $19(17.8)$ & $24(22.4)$ & $3(2.8)$ & $3(2.8)$ & $\mathrm{o}(0)$ & $61(57.0)$ & $58(54.2)$ & $3(2.8)$ \\
\hline
\end{tabular}

ESBL: extended-spectrum beta-lactamases.

a The Providencia rettgeri and the Serratia marcescens isolates were excluded because of their natural resistance to colistin.

The percentages are rounded so as to add up to $100 \%$.

Phylogenetic groups of the

\section{Escherichia coli isolates}

More than half of $E$. coli isolates belonged to the phylogenetic group $\mathrm{D}$ ( 14 of the $24 \mathrm{E}$. coli isolates), seven $E$. coli isolates belonged to the phylogenetic group $A$, two belonged to the phylogenetic group B2, and one isolate belonged to the phylogenetic group B1 (Table 1).

\section{Mulilocus sequence typing}

The distribution of the sequence types among the $K$. pneumoniae and E. coli isolates is shown in Figures 1 and 2, respectively. ST101 was the most commonly observed ST for the $K$. pneumoniae isolates, accounting for 17 out of 67 isolates (25.4\%), followed by ST395 and ST15 (7 isolates, 10.5\%) (Figure 1). Six isolates (9\%) belonged to $\mathrm{ST}_{147}(9 \%)$ and the other isolates to diverse STs, namely ST14 $(n=4)$, ST45 $(n=4), S_{25}(n=2)$, ST392 $(n=2)$, and one to other STs (Figure 1). Among the 24 OXA-48-positive $E$. coli isolates, seven belonged to $\mathrm{ST} 38(29.2 \%)$. The remaining 17 isolates belonged to STs 10, 617, 648 and 2969 (two isolates each) and to STs 46, 69, 95, 101, 362, 410, 746, 963 and 1092 (one isolate each) (Figure 2).

Since no MLST system has been developed for typing the $E$. cloacae species, these isolates were genotyped using the DiversiLab method. E. cloacae 7 and 9 recovered from Morocco were closely related, and E. cloacae 1,2 and 5 (also from Morocco) belonged to the same cluster. The other $E$. cloacae isolates were distinct (data not shown).
Genetic location the $b l a_{\text {OXA-48 }}$ gene

Using the specific primers designed from the reference plasmid pOXA-48a of K. pneumoniae 11978 [27] to amplify its replicase gene, 99 of the 107 isolates (92.5\%) carried an IncL/M-pOXA-48a-like backbone. For the eight other isolates ( $P$. rettgeri isolate no. 15 , $E$. coli isolates no. 19 to 24 , and $E$. coli isolate no. 37), mating-out assays were performed and transconjugants harbouring the $b l a_{0 \times A-48}$ gene were obtained for $P$. rettgeri isolate no. 15 and $E$. coli isolate no. 37 . Plasmid DNA analysis of the two $E$. coli transconjugants revealed a single plasmid. Those two bla $a_{0 \times A-48}$-positive plasmids corresponded to a ca. $150 \mathrm{~kb}$ IncA/C-type plasmid identified from $P$. rettgeri isolate no. 15 from Turkey and a ca. 160-kb IncF-type plasmid from an $E$. coli isolate from France. Despite repeated attempts, transconjugants or transformants were not obtained for six of the seven $E$. coli isolates belonging to $\mathrm{ST}_{3} 8$. Interestingly, I-Ceul analysis confirmed the chromosomal location of the $b a_{0 \times A-48}$ gene in those six isolates (data not shown). Furthermore, one out of the seven bla $a_{0 \times-48}$-positive $\mathrm{ST} 38 \mathrm{E}$. coli harboured the epidemic OXA-48 IncL/M-type plasmid.

Genetic environment of the $b l a_{\mathrm{OXA}-48}$ gene The bla $a_{0 \times A-48}$ gene was flanked by two copies of IS1999. In 21 isolates (19.6\%), the upstream copy remained intact. This structure corresponded to transposon Tn1999, whereas 84 isolates (78.5\%) had a $\operatorname{Tn} 1999.2$ transposon structure in which the IS1999 is disrupted by insertion of an IS 1 R element [4]. In two isolates 


\section{FIGURE 1}

Sequence types represented among OXA-48-producing Klebsiella pneumoniae isolates, 2001-11 (n=67)

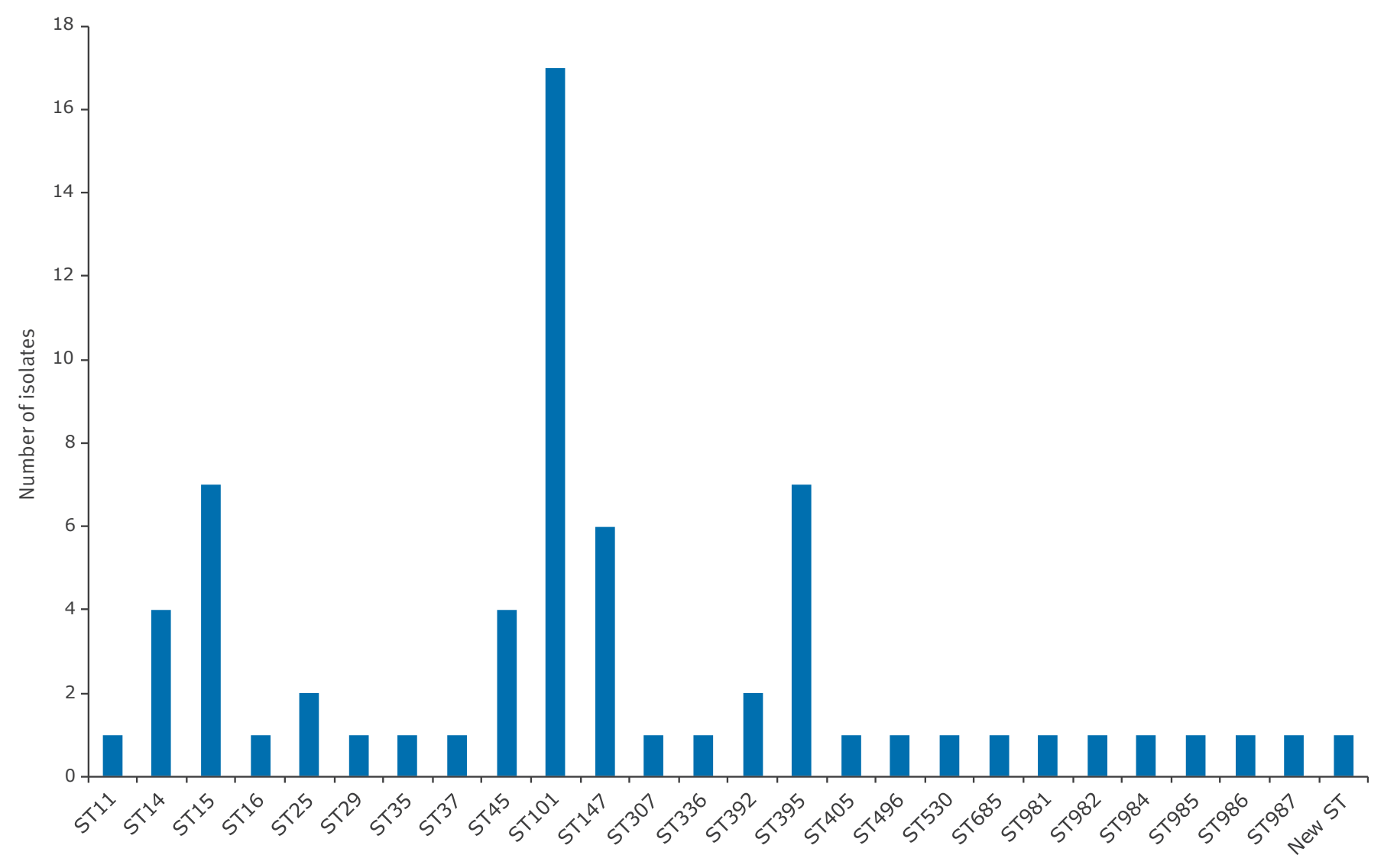

\section{FIGURE 2}

Sequence types represented among OXA-48-producing Escherichia coli isolates, 2001-11 ( $\mathrm{n}=24)$

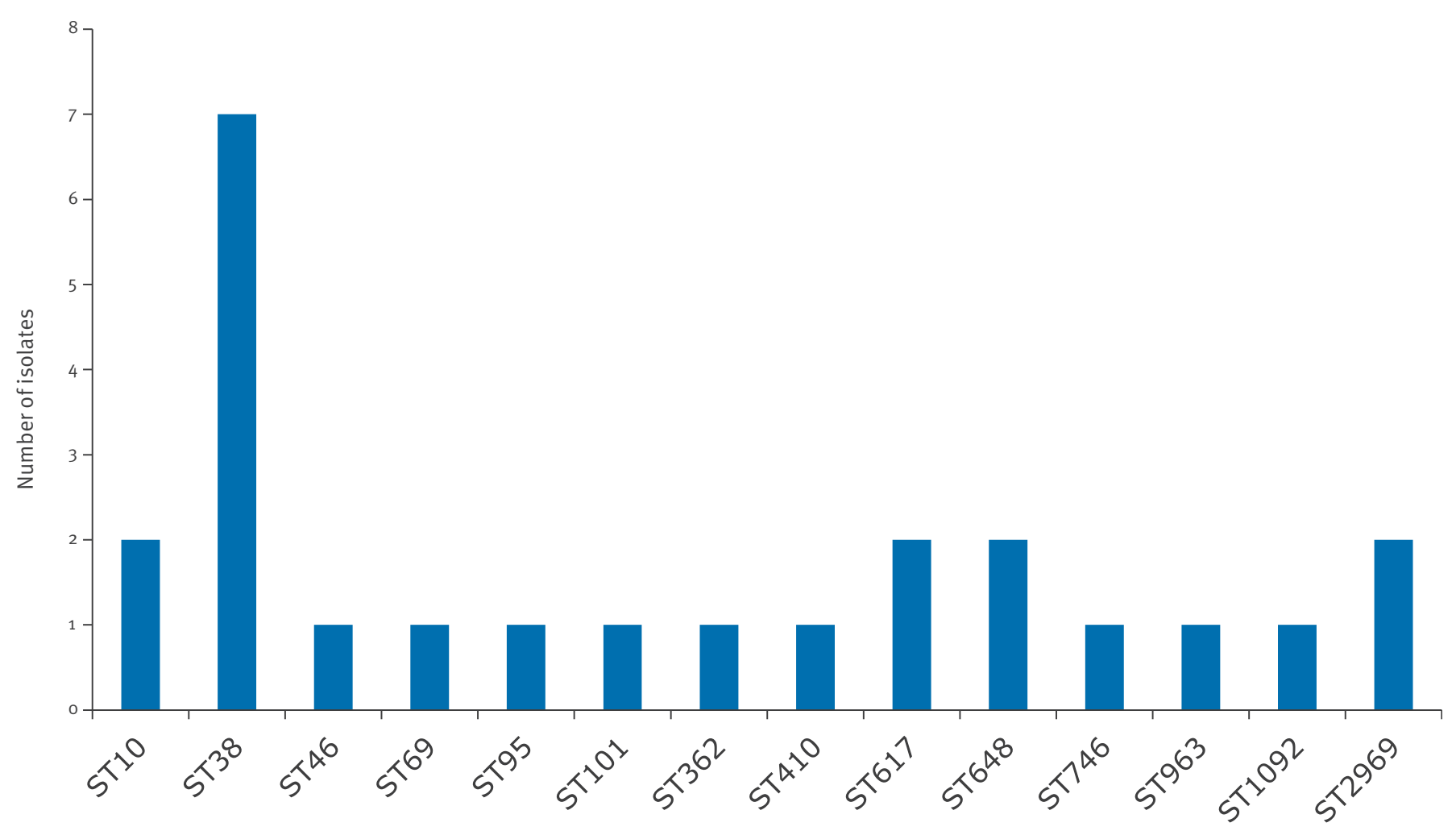


(E. cloacae isolate no. 4 and $E$. coli isolate no. 17, recovered from the same patient), a new Tn1999 derivative was identified. This new transposon Tn1999.4 was composed of Tn1999.2 disrupted by another transposon, Tn2015 which, in turn, was composed of ISECP1, bla $a_{\mathrm{CTX}-\mathrm{M}-15}$ and a truncated Tn2 transposase [32].

\section{Discussion}

We have analysed here many different features of 107 known OXA-48-positive enterobacterial isolates which are widely distributed at least in several European and North African countries, and also in Turkey. Noticeably, $25 \%$ of the OXA-48 beta-lactamase producers remained susceptible to broad-spectrum cephalosporins, which therefore present possible therapeutic options. At least positive therapeutic outcomes have been obtained using an animal model of infection and broad-spectrum cephalosporins [33]. Those ESBLnegative isolates were most often susceptible to the other classes of antibiotics, which is in line with the fact that the epidemic plasmid encoding the bla $a_{\text {oxA-48 }}$ gene does not carry additional resistance determinants [28].

However, $75 \%$ of the OXA-48-positive isolates in our study harboured an additional ESBL-encoding gene that confers resistance to broad-spectrum cephalosporins. We have recently reported the genetic association of the bla $a_{\mathrm{CTX}-\mathrm{M}-15}$ and $b l a_{\mathrm{OXA}-48}$ genes on the same transposon, indicating that this combination of multidrug-resistance genes may spread further in the future [32]. In addition, most of those ESBL-producing isolates were resistant to non-beta-lactam antibiotics, due to other resistance mechanisms. It is worth mentioning that 70 isolates $(65 \%)$ were susceptible to imipenem and meropenem according to CLSI guidelines, further complicating the detection of OXA-48-producing isolates in laboratories. Conversely, most isolates showed intermediate susceptibility or resistance to ertapenem. Ertapenem may thus be the most appropriate carbapenem molecule for detecting OXA-48 producers. Therefore, a selective medium containing ertapenem has recently been developed for the detection of all types of carbapenemase producers including the OXA48 beta-lactamase producers [34]. Taking into account the fact that $75 \%$ of the OXA-48 isolates were ESBL producers and the level of resistance to non-beta-lactam molecules, treatment options for infections caused by OXA-48 beta-lactamase producers may be limited. The efficacy of carbapenems in treating infections due to OXA-48 beta-lactamase producers with susceptibility or low-level resistance to several carbapenems remains debatable, because carbapenems have been shown to be an inefficient therapy for treating mice with induced peritonitis caused by an OXA-48-producing $K$. pneumoniae [33]. Also, imipenem-containing therapy failed to treat several OXA-48 infections in humans $[4,11]$. A single report described imipenem as efficient treatment against bacteraemia due to an 0XA-48 K. pneumoniae isolate [35]. Controlled trials are needed to evaluate the real clinical efficacy of carbapenems in treating infections due to OXA-48 beta-lactamase producers.

The clonal distribution of OXA-48 beta-lactamasepositive isolates is interesting because a quarter of the $K$. pneumoniae isolates belonged to ST101. OXA48-positive $K$. pneumoniae isolates belonging to ST101 have recently been implicated in an outbreak in Spain, and have also been detected in Tunisia $[11,12]$. We report here that the ST101 isolates were recovered from Tunisia, Morocco, and from South Africa and France from patients who did not travel abroad, suggesting that this ST has now widely spread in European countries and in Africa. Seven K. pneumoniae isolates belonged to ST395, a ST implicated in clonal outbreaks in Europe [11,14]. Interestingly, we detected seven ST15 among $K$. pneumoniae isolates recovered from patients who had a link with Morocco. That sequence type corresponds to an internationally occurring clone and has been associated with different ESBL genes, but also with the metallo-beta-lactamase genes coding for NDM and VIM $[36,37]$. The occurrence of OXA-48 betalactamase in a ST15 $\mathrm{K}$. pneumoniae isolate had been reported only once, in 2012, in an isolate from Finland [38]. Those data are likely to indicate that a novel OXA48 K. pneumoniae clone belonging to ST15 may emerge in Morocco. K. pneumoniae isolates belonging either to ST392 or ST147 (differing at a single locus) were identified in a total of eight isolates, with the two ST392 collected in Morocco and the six ST147 collected in Belgium, Turkey and France, and also from patients originating from Tunisia or Libya. This result highlights the dissemination of another OXA-48-producing clone, mainly in the Mediterranean area. The other K. pneumoniae isolates belonged to diverse ST, supporting the hypothesis of the widespread dissemination of a single bla $a_{\mathrm{OXA}-48}$-positive IncL/M plasmid among various genetic backgrounds. Overall, there is no association between ST type and ESBL type among OXA-48 producers.

Among the $24 E$. coli isolates, seven were of $\mathrm{ST}_{3} 8$, showing that this clone is widely disseminated, as previously suggested $[7,39]$. Interestingly, the $b a_{\text {OXA-48 }}$ gene was chromosomally located in six of those isolates, as was speculated for the $\mathrm{ST}_{3} 8 \mathrm{E}$. coli isolates recovered in the United Kingdom [7]. Such chromosomal location of the bla $a_{\text {OXA-48 }}$ gene in $E$. coli may be associated to a lower level of resistance (a single gene copy). The other $17 E$. coli isolates were genetically distinct. Furthermore, it is interesting to note that 16 of the 24 OXA-48-positive $E$. coli belonged to phylogenetic group $\mathrm{D}$ or $\mathrm{B} 2$, which mainly include virulent strains. The $E$. cloacae isolates were overall clonally diverse.

As suggested previously, the bla $a_{\mathrm{OXA}-48}$ gene was located on a $62 \mathrm{~kb}$ IncL/M plasmid in most of our isolates $(n=99$, $92.5 \%$ ), indicating that current spread of OXA-48 betalactamase producers is mainly related to the diffusion of this plasmid. The dissemination of the $b a_{\text {oxA-48 }}$ gene is also associated with the spread of different clones. 
Interestingly, $20 \%$ of OXA-48-producing isolates collected in France were considered to be autochthonous, indicating that the $b a_{\text {OxA-48 }}$ gene has already spread in the community in France. This latter result indicates ongoing diffusion of OXA-48-type genes in Europe.

\section{Acknowledgements}

This work was partially funded by a grant from the INSERM (U914) and the Université Paris XI, France. We thank platform Genotyping of Pathogens and Public Health (Institut Pasteur, Paris, France) for coding MLST alleles and profiles and making them available at www.pasteur.fr/mlst.

\section{References}

1. Nordmann P, Naas T, Poirel L. Global spread of carbapenemase-producing Enterobacteriaceae. Emerg Infect Dis. 2011;17(10):1791-8. http://dx.doi.org/10.3201/ eid1710.110655 PMid:22000347 PMCid:PMC3310682

2. Poirel L, Potron A, Nordmann P. OXA-48-like carbapenemase: the phantom menace. J Antimicrob Chemother. 2012;67(7):1597606. http://dx.doi.org/10.1093/jac/dks121 PMid:22499996

3. Poirel L, Héritier C, Tolün V, Nordmann P. Emergence of oxacillinase-mediated resistance to imipenem in Klebsiella pneumoniae. Antimicrob Agents Chemother. 2004;48(1):15-22. http://dx.doi.org/10.1128/AAC.48.1.15-22.2004 PMid:14693513 PMCid:PMC310167

4. Carrër A, Poirel L, Yilmaz M, Akan OA, Feriha C, Cuzon G, et al. Spread of OXA-48-encoding plasmid in Turkey and beyond. Antimicrob Agents Chemother. 2010;54(3):136973. http://dx.doi.org/10.1128/AAC.01312-09 PMid:20086157 PMCid:PMC 2825965

5. Carrër A, Poirel L, Eraksoy H, Cagatay AA, Badur S, Nordmann P. Spread of OXA-48-positive carbapenem-resistant Klebsiella pneumoniae isolates in Istanbul, Turkey. Antimicrob Agents Chemother. 2008;52(8):2950-4. http://dx.doi.org/10.1128/ AAC.01672-07 PMid:18519712 PMCid:PMC2493117

6. Adler A, Shklyar M, Schwaber MJ, Navon-Venezia S, Dhaher Y, Edgar R, et al. Introduction of OXA-48-producing Enterobacteriaceae to Israeli hospitals by medical tourism. J Antimicrob Chemother. 2011;66(12):2763-6. http://dx.doi. org/10.1093/jac/dkr382 PMid:22191089

7. Dimou V, Dhanji H, Pike R, Livermore DM, Woodford N. Characterization of Enterobacteriaceae producing OXA-48 like carbapenemases in the UK. J Antimicrob Chemother. 2012;67(7):1660-5. http://dx.doi.org/10.1093/jac/dks124 PMid:22532467

8. Glupczynski Y, Huang T, Bouchahrouf W, Rezende de Castro R, Bauraing C, Gérard M, et al. Rapid emergence and spread of OXA-48-producing carbapenem-resistant Enterobacteriaceae isolates in Belgian isolates. Int J Antimicrob Agents. 2012;39(2):168-72.

http://dx.doi.org/10.1016/j.ijantimicag.2011.10.005 PMid:22115539

9. Pfeifer Y, Schlatterer K, Engelmann E, Schiller RA, Frangenberg HR, Stiewe D, et al. Emergence of OXA-48-type carbapenemase-producing Enterobacteriaceae in German hospitals. Antimicrob Agents Chemother. 2012;56(4):2125-8. http://dx.doi.org/10.1128/AAC.05315-11 PMid:22290940 PMCid:PMC3318349

10. Poirel L, Carbonnelle E, Bernabeu S, Gutmann L, Rotimi V, Nordmann P. Importation of OXA-48-producing Klebsiella pneumoniae from Kuwait. J Antimicrob Chemother. 2012;67(8):2051-2. http://dx.doi.org/10.1093/jac/dks167 PMid:22577102

11. Cuzon G, Ouanich J, Gondret R, Naas T, Nordmann P. Outbreak of OXA-48-positive carbapenem-resistant Klebsiella pneumoniae isolates in France. Antimicrob Agents Chemother. 2011;55(5):2420-3. http://dx.doi.org/10.1128/AAC.01452-10 PMid:21343451PMCid:PMC3088266

12. Pitart C, Solé M, Roca I, Fabrega A, Vila J, Marco F. First outbreak of a plasmid-mediated carbapenem-hydrolyzing OXA$48 \beta$-lactamase in Klebsiella pneumoniae in Spain. Antimicrob Agents Chemother. 2011;55(9):4398-401. http://dx.doi.org/10.1128/AAC.00329-11 PMid:21746954 PMCid:PMC3165339
13. Voulgari E, Zarkotou O, Ranellou K, Karageorgopoulos DE, Vrioni G, Mamali V, et al. Outbreak of OXA-48 carbapenemaseproducing Klebsiella pneumoniae in Greece involving an ST11 clone. J Antimicrob Chemother. 2013;68(1):84-8. http://dx.doi. org/10.1093/jac/dks356 PMid:22945916

14. Potron A, Kalpoe J, Poirel L, Nordmann P. European dissemination of a single OXA-48-producing Klebsiella pneumoniae clone. Clin Microb Infect. 2011;17(12):E246. http://dx.doi.org/10.1111/j.1469-0691.2011.03669.x PMid:21973185

15. Clinical and Laboratory Standards Institute (CLSI). Performance standards for antimicrobial susceptibility testing; twentysecond informational supplement. CLSI document M100-S22. Wayne, PA: CLSI, 2012. Available from: http://antimicrobianos. com.ar/ATB/wp-content/uploads/2012/11/M100S22E.pdf

16. European Committee on Antimicrobial Susceptibility Testing (EUCAST). Breakpoint tables for interpretation of MICS and zone diameters, Version 2.0. EUCAST; 2012. Available from: http://www.eucast.org/fileadmin/src/ media/PDFs/EUCAST_files/Disk_test_documents/EUCAST_ breakpoints_v_2.0_120101.pdf

17. Drieux L, Brossier F, Sougakoff W, Jarlier V. Phenotypic detection of extended-spectrum $B$-lactamase production in Enterobacteriaceae: review and bench guide. Clin Microbiol Infect. 2008;14(1):90-103. http://dx.doi.org/10.1111/j.14690691.2007.01846.x PMid:18154532

18. Nordmann P, Dortet L, Poirel L. Rapid detection of extended spectrum- $\beta$-lactamase-producing Enterobacteriaceae. J Clin Microbiol. 2012;50(9):3016-22. http://dx.doi.org/10.1128/ JCM.00859-12 PMid:22760052 PMCid:PMC3421789

19. Poirel L, Dortet L, Bernabeu S, Nordmann P. Genetic features of blaNDM-1-positive Enterobacteriaceae. Antimicrob Agents Chemother. 2011;55(11):5403-7. http://dx.doi.org/10.1128/ AAC.00585-11 PMid:21859933 PMCid:PMC3195013

20. Poirel L, Walsh TR, Cuvillier V, Nordmann P. Multiplex PCR for acquired carbapenemase genes. Diagn Microbiol Infect Dis. 2011;70(1):119-23. http://dx.doi.org/10.1016/j. diagmicrobio.2010.12.002 PMid:21398074

21. Potron A, Nordmann P, Lafeuille E, Al Maskari Z, Al Rashdi F, Poirel L. Characterization of OXA-181, a carbapenemhydrolyzing class D $\beta$-lactamase from Klebsiella pneumoniae. Antimicrob Agents Chemother. 2011;55(10):4896-9. http://dx.doi.org/10.1128/AAC.00481-11 PMid:21768505 PMCid:PMC3186949

22. Poirel L, Guibert M, Girlich D, Naas T, Nordmann P. Cloning, sequence analyses, expression, and distribution of ampCampR from Morganella morganii clinical isolates. Antimicrob Agents Chemother. 1999;43(4):769-76. PMid:10103179 PMCid:PMC89205

23. Diancourt L, Passet V, Verhoef J, Grimont PA, Brisse S. Multilocus sequence typing of Klebsiella pneumoniae nosocomial isolates. J Clin Microbiol. 2005;43(8):4178 82. http://dx.doi.org/10.1128/JCM.43.8.4178-4182.2005 PMid:16081970 PMCid:PMC1233940

24. Clermont O, Bonacorsi S, Bingen E. Rapid and simple determination of the Escherichia coli phylogenetic group. Appl Environ Microbiol. 2000;66(10):4555-8. http://dx.doi. org/10.1128/AEM.66.10.4555-4558.2000 PMid:11010916 PMCid:PMC92342

25. Kieser T. Factors affecting the isolation of CCC DNA from Streptomyces lividans and Escherichia coli. Plasmid. 1984;12(1):19-36. http://dx.doi.org/10.1016/0147-619X(84)90063-5

26. Liu SL, Hessel A, Sanderson KE. Genomic mapping with I-Ceul, an intron-encoded endonuclease specific for genes for ribosomal RNA, in Salmonella spp., Escherichia coli, and other bacteria. Proc Natl Acad Sci USA. 1993;90(14):6874-8. http://dx.doi.org/10.1073/pnas.90.14.6874 PMid:8341713 PMCid:PMC47035

27. Carattoli A, Bertini A, Villa L, Falbo V, Hopkins KL, Threlfall EJ. Identification of plasmids by PCR-based replicon typing. J Microbiol Methods. 2005;63(3-:219-28.

28. Poirel L, Bonnin RA, Nordmann P. Genetic features of the widespread plasmid coding for the carbapenemase OXA48. Antimicrob Agents Chemother. 2012;56(1):559-62. http://dx.doi.org/10.1128/AAC.05289-11 PMid:22083465 PMCid:PMC3256075

29. Aubert D, Naas T, Héritier C, Poirel L, Nordmann P. Functional characterization of IS1999, an IS4 Family element involved in mobilization and expression of $\beta$-lactam resistance genes. Bacteriol. 2006;188(18):6506-14. http://dx.doi.org/10.1128/JB.00375-06 PMid:16952941 PMCid:PMC1595497

30. Jacoby G. ß-Lactamase Classification and Amino Acid Sequences for TEM, SHV and OXA Extended-Spectrum 
and Inhibitor Resistant Enzymes. Burlington: Lahey Clinic.

[Accessed Jul 2013]. Available from: www.lahey.org/studies/

31. Hidalgo L, Hopkins KL, Wareham DW, Gutierrez B, Gonzalez-

Zorn B. Association of extended-spectrum $\beta$-lactamase VEB- 5 and $16 \mathrm{~S}$ rRNA methyltransferase ArmA in Salmonella enterica from the United Kingdom. Antimicrob Agents Chemother. 2012;56(9):4985-7.

http://dx.doi.org/10.1128/AAC.00381-12 PMid:22710120

PMCid:PMC3421862

32. Potron A, Nordmann P, Rondinaud E, Jaureguy F, Poirel L. A mosaic transposon encoding OXA-48 and CTX-M-15; towards the panresistance. J Antimicrob Chemother. 2013;68(2):476-7. http://dx.doi.org/10.1093/jac/dks397 PMid:23027715

33. Mimoz O, Grégoire N, Poirel L, Marliat M, Couet W, Nordmann P. Broad-spectrum $\beta$-lactam antibiotics for treating experimental peritonitis in mice due to Klebsiella pneumoniae producing the carbapenemase OXA-48. Antimicrob Agents Chemother. 2012;56(5):2759-6o. http://dx.doi.org/10.1128/ AAC.06069-11 PMid:22330912 PMCid:PMC3346608

34. Nordmann P, Girlich D, Poirel L. Detection of carbapenemase producers in Enterobacteriaceae by use of a novel screening medium. J Clin Microb. 2012;50(8):2761-6. http://dx.doi. org/10.1128/JCM.06477-11 PMid:22357501 PMCid:PMC3421537

35. Maherault AC, Nordmann P, Therby A, Pangon B. Efficacy of imipenem for the treatment of bacteremia due to an OXA48-producing Klebsiella pneumoniae isolate. Clin Infect Dis. 2011;54(4):577-8. http://dx.doi.org/10.1093/cid/cir887 PMid:22157173

36. Poirel L, Benouda A, Hays C, Nordmann P. Emergence of NDM1-producing Klebsiella pneumoniae in Morocco. J Antimicrob Chemother. 2011;66(12):2781-3. http://dx.doi.org/10.1093/jac/ dkr384 PMid:21930570

37. Sanchez-Romero I, Asensio A, Oteo J, Munoz-Algarra M, Isidoro $B$, Vindel A, et al. Nosocomial outbreak of VIM-1-producing Klebsiella pneumoniae isolates of mutilocus sequence type 15: molecular basis, clinical risk factors, and outcome. Antimicrob Agents Chemother. 2012;56(1):420-7. http://dx.doi. org/10.1128/AAC.05036-11 PMid:22005997 PMCid:PMC3256054

38. Osterblad M, Kirveskari J, Hakanen AJ, Tissari P, Vaara M, Jalava J. Carbapenemase-producing Enterobacteriaceae in Finland: the first years (2008-11). I Antimicrob Chemother. 2012;67(12):2860-4. http://dx.doi.org/10.1093/jac/dks299 PMid:22855858

39. Poirel L, Bernabeu S, Fortineau N, Podglajen I, Lawrence C, Nordmann P. Emergence of OXA-48-producing Escherichia coli clone $\mathrm{ST}_{3} 8$ in France. Antimicrob Agents Chemother. 2011;55(10):4937-8. http://dx.doi.org/10.1128/AAC.00413-11 PMid:21768512 PMCid:PMC3186974 